\title{
Életveszélyes állapotok ellátása a fogorvosi rendelőben
}

\author{
DR. FELKAI PÉTER*, DR. KIVOVICS PÉTER**, DR. FELKAI TAMÁS***
}

\begin{abstract}
A fogorvosi beavatkozásokkal járó stressz, a hosszabb kezelési idő és a fogorvosi anesztézia széleskörű alkalmazása valószínúleg megnöveli a rendelői rosszullétek számát is. A rosszullétek prevalenciája a fogorvosi rendelőkben 19-67\% között mozog. A szakirodalom rendelőnként átlag évi 2-20 rosszullétet említ. A leggyakoribb, ellátásra szoruló esemény az összeesés, ájulás volt, és a leggyakoribb rosszulléteket a cukorbetegségből eredő hypoglikémiás roham, az allergiás reakció és a vérnyomáskiugrás okozta. A fogorvos feladata az életet veszélyeztető állapotok elhárítása, ami a szakirodalmi adatok szerint az összes rosszullétek 8-10\%-a. A megfelelő beavatkozáshoz szükséges, hogy minden rendelőben készüljön „riadóterv” a rosszullétek ellátásra, világosan megjelölve az orvos és az asszisztencia feladatát. A rendelő felszerelésére a jogszabály tárgyi feltételeket is megjelölt, ezeket azonban érdemes a fogorvosi rendelő lehetőségeinek fényében újragondolni. Ezért a szerzők javaslatot tesznek a szükséges gyógyszerek összeállítására, valamint a szükséges eszközök beszerzésére. A tárgyi feltételek mellett elengedhetetlen az orvosi elsősegélynyújtás naprakész tudása. Erre a meglevő tankönyv és a gyakori posztgraduális képzés lehetőséget ad, ami nemzetközi összehasonlításban is kiemelkedően jónak mondható.
\end{abstract}

Kulcsszavak: sürgősségi ellátás, sürgősségi táska, fogorvosi rendelő, újraélesztés, továbbképzés

\section{Bevezetés}

A fogorvosi beavatkozások széleskörūvé válásával (szájsebészeti beavatkozások, fogászati, parodontológiai mütétek stb.) a fogorvosi székben töltött idő is meghosszabbodik. A kezeléseket a korszerü müszerezettség és az anesztézia eszköztára is segíti. Nyilvánvaló, hogy a hosszabb időtartamú, bonyolultabb kezelések, a fogorvosi fájdalomcsillapítás több kockázati lehetőséget rejtenek magukban, mint ahogy azt is figyelembe kell venni, hogy a betegek túlnyomó része (ritkábban az orthodontiai páciensek) az idősebb, tehát vélhetően multimorbid páciensek köréből kerül ki.

A fenti okok miatt a rendelői rosszullétek száma is növekvőben van. A váratlan rosszullétek ellátásának fontosságára már a múlt század utolsó évtizedeiben is felfigyeltek [1], a veszély elhárításának módjai és tudnivalói azóta is a figyelem középpontjában vannak [2, 3].

Mivel bármelyik fogorvosi rendelés alatt váratlanul fordulhat elő rosszullét, szükséges, hogy a fogorvoskollégák tisztában legyenek azok gyakoriságával, az alapvető életmentő beavatkozásokkal, felkészüljenek a leggyakoribb belgyógyászati sürgősségi (a továbbiakban sürgősségi) események felismerésére és ellátására.

\section{Módszer}

Szerzők áttekintik a nemzetközi szakirodalomban ebben a témában 1994 és 2019 között megjelent jelentősebb közleményeket és útmutatásokat, melyek tájékoztatnak a leggyakoribb rosszullétek előfordulási arányáról és azok ellátásának módjairól. Áttekintésükben szerepel a rendelőben készenlétben tartandó sürgősségi beavatkozó eszközök és gyógyszerek nemzetközi és saját tapasztalatokon alapuló javaslata, a beavatkozások gyakorlati alkalmazásának kérdései, valamint a fogorvosok sürgősségi képzésének színvonala is, a vizsgált szakirodalom szerzői véleményének tükrében.

\section{Eredmények}

A sürgősségi események epidemiológiáját vizsgálva a szakirodalomban a következő adatokat találtuk: a rosszullétek prevalenciája a fogorvosi rendelőkben: $19-44 \%$ [4], sőt egyes felmérések szerint $67 \%$ [5] között mozog. A sürgősséginek ítélt események legtöbbje (90\%) könnyen ellátható volt, de a súlyos esetek száma is $8-10 \%$ körüli [4]. Brit források átlag évi 20 [6], újzélandi szerzők évi 2 rosszullétről számolnak be rendelőnként [7]; egy német felmérés szerint a rendelők 
Sürgősségi esetek megoszlása a fogorvosi rendelökben. Az egymástól nagyon eltérő adatok a sürgősségi állapotok nem egységes értelmezéséból adódnak.

\begin{tabular}{|c|c|c|c|c|c|c|c|c|c|}
\hline Tünet & $\begin{array}{c}\text { Elöfordulás } \\
\text { (case / dentist } \\
\text { / year) [13] }\end{array}$ & $\begin{array}{c}\text { Elöfor } \\
\text { dulás \% } \\
\text { [6] }\end{array}$ & $\begin{array}{c}\text { Elöfor } \\
\text { dulás \% } \\
\text { [10] }\end{array}$ & $\begin{array}{c}\text { Előfor } \\
\text { dulás \% } \\
\text { [11] }\end{array}$ & $\begin{array}{c}\text { Előfor } \\
\text { dulás \% } \\
\text { [12] }\end{array}$ & $\begin{array}{c}\text { Elöfor } \\
\text { dulás \% } \\
\text { [5] }\end{array}$ & $\begin{array}{c}\text { Elöfor } \\
\text { dulás \% } \\
\text { [16] }\end{array}$ & $\begin{array}{c}\begin{array}{c}\text { Elöfor } \\
\text { dulás \% } \\
{[14]}\end{array} \\
\end{array}$ & $\begin{array}{c}\text { Elófor } \\
\text { dulás \% } \\
\text { [15] }\end{array}$ \\
\hline $\begin{array}{l}\text { presyncope, syncope } \\
\text { (ájulás, eszméletvesztéssel) }\end{array}$ & 1,90 & $\begin{array}{c}31- \\
36,3 \%\end{array}$ & $\begin{array}{c}54,2- \\
12,65 \%\end{array}$ & $0,004 \%$ & $40,9 \%$ & $53,1 \%$ & $\mathrm{~N} / \mathrm{A}$ & $\mathrm{N} / \mathrm{A}$ & $\mathrm{N} / \mathrm{A}$ \\
\hline $\begin{array}{l}\text { collapszus (összeesés), } \\
\text { orthostatikus hypotensio }\end{array}$ & $\mathrm{N} / \mathrm{A}$ & N/A & $44,33 \%$ & $\mathrm{~N} / \mathrm{A}$ & $\mathrm{N} / \mathrm{A}$ & $\mathrm{N} / \mathrm{A}$ & $\mathrm{N} / \mathrm{A}$ & $16,0 \%$ & $18,9 \%$ \\
\hline $\begin{array}{l}\text { vérnyomáskiugrás, } \\
\text { hypertensiós crisis }\end{array}$ & 0,02 & N/A & $15 \%$ & $\mathrm{~N} / \mathrm{A}$ & $\mathrm{N} / \mathrm{A}$ & $\mathrm{N} / \mathrm{A}$ & $\mathrm{N} / \mathrm{A}$ & $\mathrm{N} / \mathrm{A}$ & $\mathrm{N} / \mathrm{A}$ \\
\hline $\begin{array}{l}\text { anginás panaszok } \\
\text { / mellkasi diszkomfortérzés }\end{array}$ & 0,19 & $\begin{array}{l}10,1- \\
11,0 \%\end{array}$ & $6,80 \%$ & $\mathrm{~N} / \mathrm{A}$ & $0,9 \%$ & $\mathrm{~N} / \mathrm{A}$ & $10,1 \%$ & $\mathrm{~N} / \mathrm{A}$ & $\mathrm{N} / \mathrm{A}$ \\
\hline convulsió, görcsök & 0,13 & $\mathrm{~N} / \mathrm{A}$ & $6,20 \%$ & $0,0005 \%$ & $7,6 \%$ & $\mathrm{~N} / \mathrm{A}$ & $31,0 \%$ & $8,8 \%$ & $11,8 \%$ \\
\hline $\begin{array}{l}\text { hypoglycaemia } \\
\text { (diabeteses szövődmény) }\end{array}$ & 0,17 & $\begin{array}{l}10,6- \\
9,0 \%\end{array}$ & $5,60 \%$ & $0,002 \%$ & $37,1 \%$ & $44,8 \%$ & $10,6 \%$ & $7,3 \%$ & $16,0 \%$ \\
\hline hyperventillatio & $\mathrm{N} / \mathrm{A}$ & $\mathrm{N} / \mathrm{A}$ & $5,20 \%$ & $\mathrm{~N} / \mathrm{A}$ & $7,0 \%$ & $\mathrm{~N} / \mathrm{A}$ & N/A & $7,5 \%$ & $18,6 \%$ \\
\hline csuklás & $\mathrm{N} / \mathrm{A}$ & $\mathrm{N} / \mathrm{A}$ & $2,20 \%$ & N/A & $\mathrm{N} / \mathrm{A}$ & $\mathrm{N} / \mathrm{A}$ & $\mathrm{N} / \mathrm{A}$ & $\mathrm{N} / \mathrm{A}$ & N/A \\
\hline ictus cerebri & $\mathrm{N} / \mathrm{A}$ & N/A & $0,80 \%$ & $\mathrm{~N} / \mathrm{A}$ & $\mathrm{N} / \mathrm{A}$ & $\mathrm{N} / \mathrm{A}$ & $36.30 \%$ & $\mathrm{~N} / \mathrm{A}$ & $\mathrm{N} / \mathrm{A}$ \\
\hline $\begin{array}{l}\text { anafilaxiás shock } \\
\text { / allergiás reakció }\end{array}$ & 0,01 & N/A & $\begin{array}{l}16,7 \% \\
/ 0,4 \% \\
\end{array}$ & $0,0009 \%$ & $17,1 \%$ & $17,1 \%$ & $\mathrm{~N} / \mathrm{A}$ & $13,8 \%$ & $16,2 \%$ \\
\hline myocardialis infarctus & N/A & $\mathrm{N} / \mathrm{A}$ & $0,20 \%$ & N/A & $\mathrm{N} / \mathrm{A}$ & $\mathrm{N} / \mathrm{A}$ & $\mathrm{N} / \mathrm{A}$ & $\mathrm{N} / \mathrm{A}$ & $\mathrm{N} / \mathrm{A}$ \\
\hline szívmegállás & $\mathrm{N} / \mathrm{A}$ & $\mathrm{N} / \mathrm{A}$ & $0,20 \%$ & $\mathrm{~N} / \mathrm{A}$ & $\mathrm{N} / \mathrm{A}$ & $\mathrm{N} / \mathrm{A}$ & $\mathrm{N} / \mathrm{A}$ & N/A & $\mathrm{N} / \mathrm{A}$ \\
\hline asthma & 0,06 & $\begin{array}{l}13,48- \\
11,1 \%\end{array}$ & N/A & $\mathrm{N} / \mathrm{A}$ & $4,5 \%$ & N/A & $13,80 \%$ & $\mathrm{~N} / \mathrm{A}$ & $\mathrm{N} / \mathrm{A}$ \\
\hline anesztéziai komplikáció & N/A & N/A & N/A & $0,002 \%$ & $\mathrm{~N} / \mathrm{A}$ & N/A & N/A & N/A & N/A \\
\hline fulladás & 0,09 & N/A & N/A & N/A & $\mathrm{N} / \mathrm{A}$ & N/A & $\mathrm{N} / \mathrm{A}$ & N/A & N/A \\
\hline idegentest aspiráció & $\mathrm{N} / \mathrm{A}$ & $\begin{array}{l}15,7- \\
18,1 \%\end{array}$ & $\mathrm{~N} / \mathrm{A}$ & $0,001 \%$ & $\mathrm{~N} / \mathrm{A}$ & $5,5 \%$ & $15,7 \%$ & $\mathrm{~N} / \mathrm{A}$ & $\mathrm{N} / \mathrm{A}$ \\
\hline
\end{tabular}

57-70\%-ában [8] történik egy vagy több sürgősséginek nevezhető esemény [9], legtöbbször általános anesztéziában végzett beavatkozásoknál. A rosszullétek fajtáinak megoszlását az 1. táblázat mutatja.

Az ellátásra szoruló, sürgős - vagy annak látszó - esetekben szükséges beavatkozásokhoz meg kell lennie a megfelelő gyógyszeres és eszközös felszerelésnek. Több, fejlett gazdasági háttérrel rendelkező országgal ellentétben, hazánkban a fogorvosi rendelőkben történő sürgősségi esetek ellátásához szükséges gyógyszereket és eszközöket jogszabály teszi kötelezővé. ${ }^{1} \mathrm{~A}$ fogászati ellátás (szakmakód: 1300, 1301, 1302, 1303, $1304,1305,1308$ ) keretében a fogorvosi rendelők szakmai minimumfeltételeinek felsorolásakor a rendelő általános feltételei mellett sürgősségi vagy készenléti táska/ tálca megléte is szükséges.

Sajnálatos módon, a rendelet egyáltalán nem veszi figyelembe a fogorvosi sürgősségi esetek körülményeit és kívánalmait, ugyanis a rendelet a sürgősségi táska

1 60/2003 (X.20) ESZCSM rendelet az egészségügyi szolgáltatások nyújtásához szükséges szakmai minimumfeltételekről, 2 . sz. melléklet. eszköz- és gyógyszerfelszereltségét a központi orvosi ügyelet (szakmakód: 4601) tárgyi feltételeinél rögzíti, így több olyan tétel is található a felsorolásban, ami a fogorvosi sürgősségi ellátásnál nem szükséges. Az általános anesztéziában végzett fogászati ellátás (szakmakód: 1309) tárgyi feltételei között ismételten megemlíti „a rendelő általános feltételei + alapellátás műszerei és sürgősségi vagy készenléti táska/tálca" meglétét.

Amíg a sürgősségi táska kötelező felszerelését a fenti rendelet szabályozza, addig a készenléti táska tartalmára nincs világos állásfoglalás. ${ }^{2} \mathrm{~A}$ készenléti tálca/ táska tartalmát vélhetőleg az újraélesztő tálca fogalmával fedi le a jogszabály, ${ }^{3}$ melynek minimumtartalmát is megadja a rendelet. ${ }^{4} \mathrm{~A}$ készenléti tálca tartalma nagyjából megegyezik a sürgősségi táska tartalmával, az egyetlen különbség a motoros meghajtású leszívó készülék, illetve laringoszkóp a hozzá tartozó (vélhetően intratracheális) tubussorozattal. Mivel endotracheális

2 Egyébként az orvosi rendelőkben előírt „orvosi táskára” sem.

3 1. számú melléklet a 60/2003. (X. 20.) ESZCSM rendelethez, 3.4 bekezdés

4 1. sz. melléklet az 1/2012. (V. 31.) EMMI rendelethez, 4.2 bekezdés 
A fogorvosi sürgősségi táskában tartandó javasolt injekciók

\begin{tabular}{|c|c|c|c|c|c|c|}
\hline $\begin{array}{l}\text { Gyógyszer } \\
\text { nemzetközi } \\
\text { szabad neve } \\
\text { (hatóanyag) }\end{array}$ & Gyári név & Kiszerelés & $\begin{array}{c}\text { Hatóanyag- } \\
\text { tartalom a } \\
\text { kiszerelésben }\end{array}$ & $\begin{array}{c}\text { Adagolás } \\
\text { sürgősségi } \\
\text { helyzetben, } \\
\text { maximum dózis, } \\
\text { felnőtteknek }\end{array}$ & \begin{tabular}{|l|} 
Adagolás \\
sürgősségi \\
helyzetben, \\
maximum dózis, \\
gyermekeknek \\
\end{tabular} & Fö indikáció \\
\hline \multirow[t]{4}{*}{ epinephrine } & \multirow[t]{4}{*}{ Tonogen } & \multirow[t]{4}{*}{$1 \mathrm{ml}$} & \multirow[t]{4}{*}{$1 \mathrm{mg}$} & $\begin{array}{c}\text { CPR: } 1 \mathrm{mg} \\
\text { 3-5 percenként }\end{array}$ & 6-12 év: $0,3 \mathrm{mg} \mathrm{im}$ & újraélesztés (CPR) \\
\hline & & & & & 6 év alatt: $0,15 \mathrm{mg}$ im & allergiás reakció \\
\hline & & & & bradycardia esetén: & $\begin{array}{l}\text { CPR: } 10 \mu \mathrm{g} / \mathrm{ttkg} \\
3 \text { percenként iv }\end{array}$ & asthmás roham \\
\hline & & & & $2-10 \mu \mathrm{g} / \mathrm{min}$ & Egyéb: $0,01 \mathrm{mg} / \mathrm{kg}$ iv & bradicardia \\
\hline \multirow{2}{*}{$\begin{array}{l}\text { metamizole } \\
\text { sodium }\end{array}$} & \multirow[t]{2}{*}{ Algopyrin } & \multirow[t]{2}{*}{$2 \mathrm{ml}$} & \multirow[t]{2}{*}{$1 \mathrm{gr}$} & \multirow[t]{2}{*}{$2 \mathrm{gr}$} & \multirow[t]{2}{*}{$10-20 \mathrm{mg} / \mathrm{ttkg}$} & fájdalomcsillapítás \\
\hline & & & & & & lázcsillapítás \\
\hline atropinum & $\begin{array}{l}\text { Atropinum } \\
\text { Sulfuricum }\end{array}$ & $1 \mathrm{ml}$ & $1 \mathrm{mg}$ & CPR: egyszeri $3 \mathrm{mg}$ & $0,01-0,02 \mathrm{mg} / \mathrm{ttkg}$ iv & $\begin{array}{l}\text { premedikációkor } \\
\text { a salivatio } \\
\text { csökkentése, } \\
\text { bradycardia } \\
\text { mérséklése } \\
\end{array}$ \\
\hline diazepam & $\begin{array}{l}\text { Diazepam } \\
\text { desitin }\end{array}$ & $\begin{array}{c}\text { végbélbe } \\
\text { vezethető } \\
\text { tubusban } \\
2,5 \mathrm{ml} \text { oldat }\end{array}$ & $10 \mathrm{mg}$ & $\begin{array}{c}\text { A tubust, } \\
\text { a végét lefelé tartva, } \\
\text { teljesen vezesse be } \\
\text { a végbélnyílásba, } \\
2 \text { ampullát adjunk } \\
\text { egymás után } \\
(20 \mathrm{mg}) \\
\end{array}$ & $\begin{array}{l}15 \text { ttkg alatti gyermekek } \\
\text { esetében csak félig } \\
\text { nyomja be a végbél- } \\
\text { tubust és tartalmát: } \\
10 \mathrm{~kg} \text { alatti testtömeg } \\
\text { esetén } 5 \mathrm{mg} \text {, } \\
10 \mathrm{~kg} \text { felett } 10 \mathrm{mg} \\
\end{array}$ & $\begin{array}{l}\text { görcsroham, } \\
\text { epilepsziás roham }\end{array}$ \\
\hline \multirow[t]{2}{*}{ diazepam } & \multirow[t]{2}{*}{ Seduxen } & \multirow[t]{2}{*}{$2 \mathrm{ml}$} & \multirow[t]{2}{*}{$10 \mathrm{mg}$} & $10,20 \mathrm{mg}$ iv & $\begin{array}{l}0,1-0,5 \mathrm{mg} / \mathrm{kg} \text { iv } \\
\text { (status epilepticus } \\
\text { esetén) }\end{array}$ & $\begin{array}{l}\text { görcsroham, } \\
\text { epilepsziás roham }\end{array}$ \\
\hline & & & & $0,1-0,2 \mathrm{mg} / \mathrm{ttkg}$ & $\begin{array}{l}0,04-0,2 / \mathrm{kg} \text { iv } \\
\text { (sedatio) }\end{array}$ & sedatio \\
\hline \multirow[t]{2}{*}{ aminodaron } & \multirow[t]{2}{*}{ Cordarone } & \multirow[t]{2}{*}{$3 \mathrm{ml}$} & \multirow[t]{2}{*}{$50 \mathrm{mg}$} & $300 \mathrm{mg}$ & \multirow{2}{*}{$\begin{array}{l}5 \text { mg/ttkg malignus } \\
\text { ritmuszavar esetén }\end{array}$} & \multirow{2}{*}{$\begin{array}{l}\text { malignus } \\
\text { ritmuszavarok } \\
\text { (kamrafibrilláció, } \\
\text { kamrai tachycardia), } \\
\text { CPR alatt }\end{array}$} \\
\hline & & & & $\begin{array}{c}\text { CPR esetén } \\
300 \text { mg + } 150 \text { mg } \\
\text { ismételhető. } \\
\text { Lassan injektálandó! }\end{array}$ & & \\
\hline uradipin & Ebrantil & $10 \mathrm{ml}$ & $50 \mathrm{mg}$ & $\begin{array}{c}\text { 5-10 mg-os } \\
\text { lassú bólusokban }\end{array}$ & $\begin{array}{l}\text { gyermekeknek } \\
\text { fogorvosi rendelőben } \\
\text { nem adható }\end{array}$ & $\begin{array}{l}200 \text { Hgmm } \\
\text { feletti magas } \\
\text { vérnyomás hirtelen } \\
\text { csökkentésére } \\
\end{array}$ \\
\hline aminophylline & $\begin{array}{l}\text { Diaphyllin } \\
\text { venosum }\end{array}$ & $5 \mathrm{ml}$ & $240 \mathrm{mg}$ & $\begin{array}{c}1 \text { amp. lassan } \\
\text { vagy infúzióban }\end{array}$ & $\begin{array}{l}\text { gyermekeknek } \\
\text { fogorvosi rendelőben } \\
\text { nem adható }\end{array}$ & $\begin{array}{l}\text { asthmás roham } \\
\text { esetén }\end{array}$ \\
\hline \multirow[t]{4}{*}{ chloropyramine } & \multirow[t]{4}{*}{ Suprastin } & \multirow[t]{4}{*}{$1 \mathrm{ml}$} & \multirow[t]{4}{*}{$25 \mathrm{mg}$} & \multirow[t]{4}{*}{$\begin{array}{c}\text { 0,3-0,6 mg/ttkg; } \\
1 \text { amp. }\end{array}$} & \begin{tabular}{|l|} 
Kezdő dózis: \\
1-12 hónapos \\
gyermeknek: \\
$1 / 4$ ampulla iv, im. \\
\end{tabular} & \multirow[t]{4}{*}{$\begin{array}{l}\text { enyhe allergiás } \\
\text { reakció esetén, } \\
\text { viszketés, urticaria }\end{array}$} \\
\hline & & & & & $\begin{array}{l}\text { 1-6 év: } \\
1 / 2 \text { ampulla iv, im. }\end{array}$ & \\
\hline & & & & & $\begin{array}{l}\text { 6-12 év: } \\
1 / 2-1 \text { ampulla iv, im. }\end{array}$ & \\
\hline & & & & & $\begin{array}{l}\text { Sz. sz. } \\
\text { az adag növelhető } \\
\text { max. } 2 \text { mg/ttkg-ig }\end{array}$ & \\
\hline glucose & $\begin{array}{c}\text { Glucosum } \\
20 \%\end{array}$ & $100 \mathrm{ml}$ & $220 \mathrm{gr}$ & lassan, infúzióban & $\begin{array}{l}\text { gyermekeknek } \\
\text { fogorvosi rendelőben } \\
\text { nem adható }\end{array}$ & $\begin{array}{l}\text { hypoglikémiás } \\
\text { kóma, rosszullét }\end{array}$ \\
\hline
\end{tabular}


intubálásban a fogorvosok kevéssé jártasak, motoros szívó pedig minden fogorvosi rendelőben van, így a készenléti tálca előírásának megléte a nem általános anesztéziában végzett beavatkozásokat végző rendelőben irreleváns. Sajnálatos módon azonban egyik táska/tálca előírásai között sem szerepel a darabos szívó, az oxigénterápiához szükséges maszk vagy orrszonda, és az ujjvédő.

Szerencsére az Országos Szakfelügyeleti Módszertani Központ állásfoglalása [36] lehetővé teszi a gyógyszerelés egyéni összeállítását is. Ez utóbbi javallat igen fontos a fogorvosi sürgősségi esetben alkalmazott gyógyszerek összeállításakor, mert az aktuálisan kapható termékek köre változik, valamint a rendelet előírta gyógyszerek/eszközök egy része értelmezhetetlen a fogorvosi járóbeteg ellátásban. Mivel a rendeletek nem veszik figyelembe a fogorvosi rendelő és az általános orvosi rendelő közötti szakmai- és eszközös különbségeket, jelen közleményben javaslatot teszünk a fogorvosi sürgősségi táska konkrét tartalmára.

A rendelőben tartandó gyógyszerek listáját több közlemény is felsorolja $[4,17,18,19,20]$, ezeket figyelembe véve a fogorvosi sürgősségi táska ideális gyógyszer-összeállítását a 2., 3. és a 4. táblázat tartalmazza. Nyilvánvaló, hogy sürgősségi esetben csak a vénás injekció adása jön szóba, ezért az ajánlások is ezt a kiszerelési formát javasolják (2. táblázat)

Sürgős esetben javasolt a vénásan adott gyógyszereket infúzió bekötése után a szereléken található gumi összekötő csőbe adni. Az infúziós terápiához szükséges felszereléseket a 3. táblázatban foglaltuk össze.

3. táblázat

A fogorvosi sürgősségi táskában tartandó javasolt infúziók és infúziós felszerelés

\begin{tabular}{|l|c|}
\hline Infúziók & Mennyiség \\
\hline $100 \mathrm{ml} 40 \%-0 s$ Glucose & 2 ampulla \\
\hline $500 \mathrm{ml}$ Salsol oldatos infúzió & 1 üveg \\
\hline $250 \mathrm{mIRinger-laktát} \mathrm{HHO}$ & 1 üveg \\
\hline vénaleszorító gumi & $\mathrm{x}$ \\
\hline érfogó anatómiás (Kocher vagy Pean fogó) & $2 \mathrm{db}$. \\
\hline $\begin{array}{l}\text { perifériás intravénás kanül (22 és } 33 \mathrm{G} \\
\text { méretben) }\end{array}$ & $2-2 \mathrm{db}$. \\
\hline Aqua destillata & $2 \mathrm{amp}$. \\
\hline infúziós szerelék & $2 \mathrm{db}$ \\
\hline
\end{tabular}

Néhány esetben tablettában, illetve sprayben is adhatjuk a gyógyszereket (4. táblázat).

A fogorvosi praxisban használható sürgősségi táska tartalmát kiegészítendő, a sürgős esetek ellátásához szükséges egyéb felszerelésre is szükség van: útmutatásul az 5. táblázat szolgálhat. Az itt található eszkö- zök jó részét a nemzetközi szakirodalom is ajánlja [21, 22, 23]. Így több szerző is javasolja az eszközök között az EKG monitort, az automata defibrillátort $[21,24,25$, 26] és a pulzoximétert is [27]. Mivel a komplett EKG monitorok meglehetősen drágák, véleményünk szerint az egyszerü riasztófunkcióval ellátott, pulzoximéter készülékek is megfelelőek lehetnek $\mathrm{a} \mathrm{SaO}_{2}$ és a szívritmus monitorozására [28].

5. táblázat

A sürgős esetek ellátásához ajánlott eszközök (készenléti táska helyett a sürgősségi táskába)

\begin{tabular}{|l|c|}
\hline Eszköz & Mennyiség \\
\hline lélegeztető maszk 3, 4, 5 méretű & $1-1 \mathrm{db}$ \\
\hline lélegeztető ballon & $1 \mathrm{db}$ \\
\hline $\begin{array}{l}\text { száj-garat tubus, 1-2-3 méret } \\
\text { (orofaringeális vagy Mayo tubus) }\end{array}$ & $1-1 \mathrm{db}$ \\
\hline leszívó pumpa & $1 \mathrm{db}$ \\
\hline leszívó katéter, 12 és 16 Ch & $2-2 \mathrm{db}$ \\
\hline darabos leszívó palack & $1 \mathrm{db}$ \\
\hline laryngealis tubus & $1 \mathrm{db}$ \\
\hline idegentest-fogó (Magill-fogó) & $1 \mathrm{db}$ \\
\hline ujj-harapásvédő & $1 \mathrm{db}$ \\
\hline oxigén belélegeztetéshez maszk & $2 \mathrm{db}$ \\
\hline $\begin{array}{l}\text { oxigén belélegeztetéshez orrkanül } \\
\text { (orrszonda) }\end{array}$ & $2 \mathrm{db}$ \\
\hline $\begin{array}{l}\text { vérnyomásmérő felnőtt és gyermekméretű, } \\
\text { mandzsettákkal }\end{array}$ & $1 \mathrm{db}$ \\
\hline fonendoszkóp & $1 \mathrm{db}$ \\
\hline $\begin{array}{l}\text { vércukorméró, tesztcsíkokkal } \\
\text { és vérvételi lándzsákkal }\end{array}$ & $1 \mathrm{készlet}$ \\
\hline pulzoximéter & $1 \mathrm{db}$ \\
\hline
\end{tabular}

A rosszullétek súlyossága, az életet veszélyeztető állapotok felismerése alapja az eredményes beavatkozásnak. A különböző országokban készült felmérések szerint azonban az ott praktizáló fogorvosok sürgősségi eseményekre felkészültsége, a tennivalók és eszközök, a gyógyszerek használata sok kívánnivalót hagy maga után [12, 24, 29, 30, 41]. A felmérések azt mutatják, hogy a fejlett és kevésbé fejlett országokban is ugyanolyan szegényes sürgősségi ellátási tudást tapasztaltak a tanulmányok készítői [39, 40]. Felmérések szerint csak a fogorvosok $20,8 \%$-a tudott adekvát diagnózist felállítani [13], és csak kevesebb, mint $60 \%$-uk tudott megfelelő újraélesztést végrehajtani [19]. Sürgősségi felszerelés csak a kérdezettek egynegyedénél volt található, az is hiányosan [38]. Kevéssé fejlett országokban a fogorvosi rendelőkben egyáltalán nem volt újraélesztéshez szükséges felszerelés [31]. Az idézett szakirodalmi adatok legtöbbje sajnos egy évtizednél idősebb, remélhetően azóta az eredmények javultak. A szegényes gyakorlati tudást megfelelő szinten tartó tanfolyamokkal kívánatos pótolni [32]. 
A fogorvosi sürgősségi táskában tartandó javasolt tablettás gyógyszerek

\begin{tabular}{|c|c|c|c|c|c|c|}
\hline $\begin{array}{l}\text { Gyógyszer } \\
\text { nemzetközi } \\
\text { szabad neve } \\
\text { (hatóanyag) }\end{array}$ & Gyári név & Kiszerelés & $\begin{array}{l}\text { Hatóanyag } \\
\text { tartalom a } \\
\text { kiszerelésben }\end{array}$ & $\begin{array}{l}\text { Adagolás } \\
\text { sürgősségi } \\
\text { helyzetben, } \\
\text { maximum dózis, } \\
\text { felnőtteknek }\end{array}$ & $\begin{array}{l}\text { Adagolás } \\
\text { sürgősségi } \\
\text { helyzetben, } \\
\text { maximum dózis, } \\
\text { gyermekeknek }\end{array}$ & Fö indikáció \\
\hline nitroglycerin & $\begin{array}{l}\text { Nitrolingual, } \\
\text { Nitromin spray }\end{array}$ & $\begin{array}{l}\text { nyelv alá } \\
\text { fújandó spray }\end{array}$ & 1 puff $=0,4 \mathrm{mg}$ & $\begin{array}{l}\text { 1-2 befújás, max. } \\
\text { három alkalommal }\end{array}$ & $\begin{array}{l}\text { gyermekeknek } \\
\text { fogorvosi } \\
\text { rendelőben nem } \\
\text { adható }\end{array}$ & $\begin{array}{l}\text { erős } \\
\text { simaizomlazító, } \\
\text { angina pectoris, } \\
\text { miocardialis } \\
\text { infarktusban, } \\
\text { tüdőödémában } \\
\text { alkalmazandó }\end{array}$ \\
\hline salbutamol & $\begin{array}{l}\text { Ventolin } \\
\text { Evohaler }\end{array}$ & $\begin{array}{l}\text { inhalációs } \\
\text { aerosol }\end{array}$ & $\begin{array}{l}1 \text { befújásnyi } \\
\text { adag (puff) } \\
100 \text { mikrogramm }\end{array}$ & $\begin{array}{l}100-200 \mu \mathrm{g} \\
\text { inhalálva (1-2 puff) }\end{array}$ & 100-200 $\mu \mathrm{g}$ inhal. & asthmás roham \\
\hline $\mathrm{NaCl}$ oldat & Salsol infúzió & $500 \mathrm{ml}$ & $4500 \mathrm{mg}$ & infúziós terápiához & $\begin{array}{l}\text { infúziós } \\
\text { terápiához }\end{array}$ & infúziós terápiához \\
\hline acetilsalicilsav & $\begin{array}{l}\text { Aszpirin, } \\
\text { Kalmopyrin, } \\
\text { Astrix }\end{array}$ & $1 \mathrm{tbl}$. & $500 \mathrm{mg}$ & $\begin{array}{l}300-500 \mathrm{mg} \\
\text { a tünetek } \\
\text { felléptekor }\end{array}$ & $\begin{array}{l}\text { gyermekeknek } \\
\text { nem adható }\end{array}$ & $\begin{array}{l}\text { infarktus } \\
\text { gyanújakor, stroke } \\
\text { gyanújakor, ACE } \\
\text { gátlót magas } \\
\text { vérnyomás esetben } \\
\text { adjuk, de hatása } \\
\text { lassan áll be! } \\
\end{array}$ \\
\hline \multirow[t]{2}{*}{ clopidrogel } & \multirow[t]{2}{*}{ Plavix } & \multirow[t]{2}{*}{$1 \mathrm{tbl}$. } & \multirow[t]{2}{*}{$75 \mathrm{mg}$} & \multirow[t]{2}{*}{300 mg (4 tbl.) } & \multirow{2}{*}{$\begin{array}{l}\text { gyermekeknek } \\
\text { nem adható }\end{array}$} & $\begin{array}{l}\text { infarktus } \\
\text { gyanújakor }\end{array}$ \\
\hline & & & & & & stroke gyanújakor \\
\hline captopril & $\begin{array}{l}\text { Tensiomin } \\
\text { vagy } \\
\text { Aceomel } 25\end{array}$ & $1 \mathrm{tbl}$. & $25 \mathrm{mg}$ & $\begin{array}{l}1 \text { tablettát bevenni } \\
\text { és } 30 \text { percet várni } \\
\text { a hatásra }\end{array}$ & $\begin{array}{l}\text { gyermekeknek } \\
\text { nem adható } \\
\text { a fogorvosi } \\
\text { rendelőben }\end{array}$ & hipertóniás krízis \\
\hline Oxygén & Orvosi oxygén & $\begin{array}{l}2 \text { literes } \\
\text { palack }\end{array}$ & 200 Bar & 4-6 lit/perc & 1 lit./perc & $\begin{array}{l}\text { mellkasi } \\
\text { fájdalom, asthma, } \\
\text { újraélesztés }\end{array}$ \\
\hline
\end{tabular}

\section{Megbeszélés}

Az életet veszélyeztető állapotok és betegségek, vagy ezek gyanújának prevalenciája magas a fogorvosi rendelőkben. Ahhoz, hogy a fogorvos a sürgős beavatkozást kívánó rosszulléteket a rendelőben korrekt módon el tudja látni, a közleményben felsorolt gyógyszereken és eszközökön kívül egy megfelelö „riadóterv”, a sürgősségi esetek ellátásának tudásanyaga és annak gyakorlása szükséges [33]. Az eszközök használatát, a gyógyszerek helyes adagolását is el kell sajátítani. Erre az évente megrendezett továbbképzések és a megjelent tankönyv [34] is segítséget nyújt. Tapasztalataink szerint hazánkban a fogorvosok ez irányú képzettsége (mely képzés az egyetemen már megkezdődik) és az ilyen irányú posztgraduális képzésen való részvétel aránya a hazai fogorvosképzést és szabályozást az átlag fölé emeli.

Az egyesült államokbeli és kanadai felmérések is azt mutatják, hogy az összeesés és az ájulás (mind- kettőt ugyanazon tünetegyüttesként tudjuk leírni, és a nemzetközi szakirodalom sem különíti el kellőképpen a syncope elnevezés alatt észlelt eseményeket) volt a leggyakoribb, azonnali beavatkozást igénylő kóresemény a fogorvosi ellátás során. Nyilvánvaló, hogy a beavatkozástól való félelem, és az, hogy a betegek a kezelés előtt nem étkeznek, a rosszullét, az ájulás leggyakoribb oka, de nem szabad figyelmen kívül hagyni a kardiális eredetü tüneteket sem, mivel egy felmérés szerint a kezelésen megjelent betegek 33\%-a krónikus szívbetegségben szenvedett [6]. A meglévő betegségek fennállásának megismerése - egy kérdőív segítségével - a kezelés előtt hatásos lehet [34]. A felmérések eredményeként kimutatott leggyakoribb rosszulléteket elsősorban a posztgraduális oktatás során kell fokozottan ismertetni.

A komoly, életet veszélyeztető kórképek ellátása öszszehangolt munkát igényel a fogorvos és az asszisztencia között. A váratlanul beálló vészhelyzetekre való felkészülés és együttmüködés alapvető tényezője an- 
nak riadótervben való írásbeli rögzítése és a terv végrehajtásának gyakorlása is [35]. A tudásanyag és a feladatmegosztás javasolt formái a fogorvos(ok) és a fogászati asszisztens(ek) között a következő5:

\section{A fogorvosnak jártasnak kell lennie:}

- a sürgős szükség, életveszély felismerésében

- a szabad légutak biztosításában

- az újraélesztés kivitelezésében

- a beteg stabil oldalfekvésbe helyezésében

- a vitális paraméterek észlelésében és monitorozásában

- a megfelelő gyógyszerelésben

A fogászati asszisztensnek jártasnak kell lennie:

- a szabad légutak biztosításában

- az újraélesztési tennivalók segítésében

- a beteg biztonsági oldalt fekvésbe helyezésében

- a vitális paraméterek észlelésében

- a mentőszolgálat kihívásában

Korán felismerésre került az, hogy mindkét szereplőnek elsődleges feladata az életveszélyes állapotok felismerése és azok elhárításának megkezdése [36]. A feladatokat részletező és azok rutinszerű gyakorlásához javasolt egy „riadóterv” készítése, amely pontosan meghatározza, hogy kinek mikor és mit kell csinálnia [2]. Ezenkívül szükséges a fogorvos kompetenciájának megfelelő sürgősségi gyógyszer és eszközkészlet is, melyeknek pontos tartalmát szakmai irányelvekben szükséges lenne rögzíteni. Reméljük, hogy a fenti javaslatok segítséget tudnak nyújtani ebben a munkában, valamint a fogorvosi elsősegélynyújtás és asszisztensképzés hatékony graduális és posztgraduális oktatásának megszervezésében, hogy a váratlan helyzetekben való beavatkozásokat készség szintűvé tegyék.

\section{Irodalom}

1. Sordyl CM, Sequin K: Mock emergency drills in dental practice. J Mich Dent Assoc 1994; 76: 32-34., 64. PMID: 9508928

2. Malamed SF: Back to basics: Emergency medicine in dentistry. J Calif Dent Assoc 1997; 25: 285-286., 288-294. PMID: 9452653

3. Roberson JB, Rothman CM: Preparing for the unexpected: are you truly ready? Five deadly misconceptions associated with medical emergency preparedness. Tex Dent J 2008; 125: 272-273. PMID: 18481615

4. HAAS, DA: Management of Medical Emergencies in the Dental Office: Conditions in Each Country, the Extent of Treatment by the Dentist. Anesth Prog 2006; 53: 20-24. https://doi.org/10.2344/0003 -3006(2006)53[20:MOMEIT]2.0.CO;2

5. Almamad M, Alnahwi T, Alshayeb H, et al: Medical emergencies encountered in dental clinic: A study from the Eastern Province of Saudi Arabia. J Family Community Med 2015; 22: 175-179. https:// doi.org/10.4103/2230-8229.163038

6. Atherton GJ, Pemberton MN, Thornhill MH: Medical emergencies: the experience of staff of a UK dental teaching hospital. Br Dent J 2000; 188: 320-324. https://doi.org/10.1038/sj.bdj.4800469

5 Fog- és szájbetegségek járóbeteg szakrendelések dolgozói számára
7. Broadbent JM, Thomson WM: The readiness of New Zealand general dental practitioners for medical emergencies. $N Z$ Dent $J$ 2001; 97: 82-86. PMID: 11695150

8. Muller MP, Hansel M, Stehr SN, Weber S, Koch T: A state-wide survey of medical emergency management in dental practices: incidence of emergencies and training experience. Emerg Med J 2008; 25: 296-300. https://doi.org/10.1136/emj.2007. 052936

9. Atherton GJ, Mccaul JA, Williams SA: Medical emergencies in general dental practice in Great Britain. Part 1: their prevalence over a 10-year period. Br Dent J 1999; 186: 72-79. https://doi.org/ 10.1038/sj.bdj.4800023

10. Arsati F, Montalli VA, Flório FM, et al: Brazilian dentists' attitudes about medical emergencies during dental treatment. $J$ Dent Educ 2010; 74: 661-666. PMID: 20516306

11. Anders PL, Comeau RL, Hatton M, et al: The Nature and Frequency of Medical Emergencies Among Patients in a Dental School Setting. J Dent Ed 2010; 74: 392-396. PMID: 20388811

12. JodALLI PS, ANKOLA AV: Evaluation of knowledge, experience and perceptions about medical emergencies amongst dental graduates (Interns) of Belgaum City, India. J Clin Exp Dent 2012; 4: e14-e18. https://doi.org/10.4317/jced.50627

13. Girdler NM, Smith DG: Prevalence of emergency events in British dental practice and emergency management skills of British dentists. Resuscitation 1999; 41: 159-167. https://doi.org/10.1016/ S0300-9572(99)00054-4

14. Smereka J, Aluchna M, Aluchna A, et al: Medical emergencies in dental hygienists' practice. Medicine (Baltimore) 2019; 98: e16613. https://doi.org/10.1097/MD.0000000000016613

15. Smereka J, Aluchna M, Aluchna A, et al: Preparedness and attitudes towards medical emergencies in the dental office among Polish dentists. Int Dent J 2019; 69: 321-328. https://doi.org/10. 1111/idj.12473

16. PoswiLlo DE: Medical emergencies in general dental practice are uncommon but they do occur. Br Dent J 1999; 186, 2, 70. https:// doi.org/10.1038/sj.bdj.4800022

17. Rosenberg, M: Preparing for Medical Emergencies. J Am Dent Assoc 2010; 141, Suppl. 1: S14-S19. https://doi.org/10.14219/ jada.archive.2010.0351

18. Dyм H: Preparing the dental office for medical emergencies. Dent Clin North Am 2008; 52: 605-608. https://doi.org/10.1016/j. cden.2008.02.010

19. Khami MR, Yazdani R, Afzalimoghaddam M, Razeghi S, Moscowchi A: Medical Emergency Management among Iranian Dentists. J Contemp Dent Pract 2014; 15: 693-698. https://doi.org/10.5005/ jp-journals-10024-1601

20. Lizardi PG, Puerta PL, Silva GR, et al: Botiquín para el manejo de urgencias médicas en el consultorio dental. Revista ADM 2012; 69,5: 214-217.

21. Boyd BC, Fantuzzo JJ, Votta T: The role of automated external defibrillators in dental practice. N Y State Dent J 2006; 72: 2023. PMID: 16925008

22. Greenwood M: Medical emergencies in dental practice: 1 . The drug box, equipment and general approach. Dent Update 2009; 36: 202-204, 207-208, 211 https://doi.org/10.12968/denu.2009. 36.4.202

23. Greenwood M, Meechan JG: General medicine and surgery for dental practitioners: part 2. Medical emergencies in dental practice: the drug box, equipment and basic principles of management. Br Dent J 2014; 216: 633-637. https://doi.org/10.1038/sj. bdj.2014.447

24. Al-Hassan M, Alquahtani S: Preparedness of dental clinic for medical emergencies in Ryjadh, Saudi-Arabia. Saudi Dent $J$ 2019; 31: 115-121. https://doi.org/10.1016/j.sdentj.2018.11.006

25. Dym H, Barzani G, Mohan N: Emergency Drugs for the Dental Office. Dental Clinics 2016; 60: 287-294. https://doi.org/10.1016/ j.cden.2015.11.001

26 Laurent F, Augustin P, Zak C, Maman L, Segai N: Preparedness of dental practices to treat cardiac arrest: Availability of defibrilla- 
tors. Resuscitation 2011; 82: 1468-1469. https://doi.org/10.1016/ j.resuscitation.2011.06.013

27. Товаск SL: Medical Emergency Preparedness in Office Practice. Am Fam Physician 2007; 75: 1679-1684. PMID: 17575658

28. FukuYama $H$, YaGiela JA: Monitoring of vital signs during dental care. Int Dent J 2006; 56: 102-108. https://doi.org/10.1111/j.1875 -595X.2006.tb00081.X

29. Kumarswami S, Tiwari A, Parmar M, et al: Evaluation of preparedness for medical emergencies at dental offices: A survey. $J$ Int Soc Prev Community Dent 2015; 5: 47-51. https://doi.org/10.4103/ 2231-0762.151977

30. Ehigiator O, Ehizele AO, Ugbodaga PI: Assessment of a Group of Nigerian Dental Students' Education on Medical Emergencies. Ann Med Health Sci Res 2014; 4: 248-252. https://doi.org/10.4103/ 2141-9248.129052

31. Adewole RA, Sote EO, Oke DA, et al: An assessment of the competence and experience of dentists with the management of medical emergencies in a Nigerian teaching hospital. Nig $Q J$ Hosp Med 2009; 19: 190-194. PMID: 20836329

32. Albelaihi HF, Alweneen Al, Ettish A, Alshahrani FA: Knowledge, attitude, and perceived confidence in the management of medical emergencies in the dental office: A survey among the dental students and interns. J Int Soc Prevent Communit Dent 2017; 7: 364-369. https://doi.org/10.4103/jispcd.JISPCD 414_17

34. FeLKAI P (szerk.): Életveszélyes állapotok elhárítása a fogorvosi rendelöben. Medicina Kk, 2019.

35. HAAS DA: Preparing dental office staff members for emergencies: developing a basic action plan. J Am Dent Assoc 2010; 141: Suppl 1 : 8S-13S. https://doi.org/10.14219/jada.archive.2010.0352

36. Állásfoglalás a fogorvosi rendelőben előírt sürgősségi/készenléti táska/tálca tartalmáról http://semmelweis.hu/fszoi/files/2014/08/ $\%$ C3\%811I\%C3\%A1sfoglal\%C3\%A1s-a-fogorvosi-rendel\%C5\% 91 ben-el\%C5\%91\%C3\%ADrt-s\%C3\%BCrg\%C5\%91ss\%C3\% A9gi-k\%C3\%A9szenl\%C3\%A9ti-t\%C3\%A1lca-tartalm\%C3\%A1r \%C3\%B31-2010.pdf (2020.02.05.)

37. Malamed SF: Medical emergencies in the dental surgery. Part 1: Preparation of the office and basic management. J Ir Dent Assoc 2015; 61: 302-308. PMID: 26902074

38. Gupta T, Aradhya MR, Nagaraj A: Preparedness for management of medical emergencies among dentists in Udupi and Mangalore, India. J Contemp Dent Pract 2008; 9: 92-99. PMID: 18633474 https://doi.org/10.5005/jcdp-9-5-92

39. Vaughan M, Park A, Sholapurkar A, et al: Medical emergencies in dental practice - management requirements and international practitioner proficiency. A scoping review. Aust Dent J 2018; 63 : 455-466. https://doi.org/10.1111/adj.12649

40. Skapetis T, Gerzina T, Hu W: Management of dental emergencies by medical practitioners: recommendations for Australian education and training. Emerg Med Australas 2011; 23: 142-152. https:// doi.org/10.1111/j.1742-6723.2011.01384.x

41. Al-Iryani GM, Ali FM, Alnami NH, et al: Knowledge and Preparedness of Dental Practitioners on Management of Medical Emergencies in Jazan Province. Open Access Maced J Med Sci 2018; 6: 402-405. https://doi.org/10.3889/oamjms.2018.072

\section{FelKai P, KIVOVIcs P, FeLKai T}

\section{Medical emergencies in dental practice}

The number of the medical emergencies in the dental office presumably will increase due to the prolonged duration of the interventions, the increased utilization of anesthesia and the stress of fear. The following three things are needed in order to prevent such emergencies: preparedness of the staff, availability of the appropriate medicines and devices. Authors overview the prevalence (19\% to $67 \%)$ and occurrence (2-20/year) of emergency situations in the office. The most frequent medical problem was the syncope $(16,0-54 \%$ of all emergencies), the second frequent problem was the diabetes-related problems and the third one was the hypertensive attack/crisis and allergic reactions. All the authors of the surveyed literature emphasize the importance of the "emergency plan" and the drill of the crew. Authors suggest a list of medicines and devices as an essential tool for the treatment of the medical emergencies. This suggestion can be a good source for making the existing professional guideline more accurate. Moreover, the analysis of the international literature points out the most important issues of the emergency treatment in the dental office and it can make the education more effective and the dentist fit for face to with the unforeseen and suddenly occurred emergency situations.

Keywords: medical emergency, dentistry, emergency treatment, resuscitation, education 